\title{
El mundo como feria. In(ter)dependencias editoriales en la Feria de Frankfurt
}

\section{Le monde comme une foire. In(ter) dépendances des maisons d'édition à la foire de Frankfort}

\author{
Gustavo Sorá \\ CONICET - Universidad Nacional de Córdoba \\ gustavosora@gmail.com
}

\begin{abstract}
Resumen
No es posible comprender de modo cabal la edición independiente sin relacionarla a la totalidad de los sistemas de agentes y de prácticas que caracterizan los distintos mercados nacionales de libros y los espacios editoriales internacionales que los abarcan. Tampoco sin considerar ciertas propiedades genéticas de su reciente emergencia como categoría polisémica, escurridiza, no obstante objetivable. Bajo estas premisas, mi trabajo describe y analiza la variedad de editoriales capaces de hacerse un lugar en la feria de Frankfurt, la más relevante a nivel mundial. El foco recae sobre editores de América Latina y de la Argentina en particular. A través del análisis espacial de la totalidad de la feria, los lugares de los editores son relacionados a factores institucionales y sociales que dan relieve a las relaciones entre pequeña y gran edición; editores independientes y grupos editoriales; editores y Estado; diversidad nacional y lingüística e intereses y estrategias de posicionamiento global de los organizadores de la Feria alemana. Este ejercicio analítico fue paralelo a un trabajo reflexivo elemental que permitió objetivar las condiciones de indagación de un universo de prácticas (la edición independiente) no explicitado en mis proyectos. Los preceptos de la etnografía (registrar todo lo significante) mostraron la virtud de esta forma de conocimiento en la disposición de informaciones que sólo formaron datos y objetos al enfrentarme a instancias colectivas de indagación científica: coloquios especializados, demanda de colegas, debate de ideas. Sólo así fue posible pensar la presencia de editores independientes (su significación) en un lugar de poder, aparentemente insignificante para ellos o desajustado a sus prácticas de pequeña escala.
\end{abstract}

Palabras Clave: Editores independientes y grupos de edición, Feria de Frankfurt, Argentina, etnografía, reflexividad. 


\section{Résumé}

Il n'est pas possible de comprendre de manière complète l'édition indépendante sans la rattacher à l'ensemble des systèmes d'agents et de pratiques qui caractérisent les divers marchés nationaux du livre et les espaces internationaux. Sous cette hypothèse, ce travail décrit et analyse les maisons d'édition capables de se faire une place à la Foire de Francfort, la plus importante au niveau mondial, en se concentrant sur des éditeurs d'Amérique Latine et plus particulièrement d'Argentine. A travers un analyse spatiale de la foire, les lieux des éditeurs sont mis en rapport avec des facteurs institutionnels et sociaux qui mettent en évidence les liens entre petite et grande édition, éditeurs indépendants et grands groupes d'édition, éditeurs et État, diversité nationale et linguistique avec des intérêts et stratégies de positionnement global des organisateurs allemands. Finalement, on opère un retour réflexif sur le rapport entre objet de recherche et observateur, entre édition indépendante et sciences sociales..

Mots Clés: Éditeurs indépendants et groupes d'édition, Foire de Francfort, Argentine, ethnographie, réflexivité.

"Pero al estar presente, gratuitamente, sin tener sponsors, ni embajadas, ni amigos políticos, ahí mismo abre una pregunta que engloba a los demás participantes / protagonistas / editoriales / agentes de derechos e incluso al stand honrado, porque está allí él, pero también y por sobre todo abre la pregunta hacia aquellos editores -en este caso- que no están en la feria de Frankfurt” (Winik, 2011, p. 8).

Viernes 23 de abril de 2010, 11 hr. En la Feria Internacional del Libro de Buenos Aires se realiza el evento "Cómo preparar el viaje a Frankfurt". La conferencia está a cargo de Marifé Boix García, representante para América Latina de la Austellungs und Messe GmbH (AuM), institución organizadora de la Feria del Libro de Frankfurt. En la platea están Jürgen Boos, presidente de la feria alemana, y Magdalena Faillace, embajadora extraordinaria del comité oficial para la exposición de la Argentina como país invitado de honor de aquél año. Al cierre de la conferencia, un “joven” editor se levanta desde el fondo de la platea e incomoda a las autoridades argentinas: “¿Cómo nos pueden ayudar para ir a la Feria de Frankfurt?". Le respondieron formalmente, de modo ambiguo, dando a entender que las editoriales pequeñas no tienen mucho para hacer allí. No fue un episodio casual. Por aquéllos días, el mercado editorial argentino bullía alrededor de la gran oportunidad internacional. Todos los actores del mundo del libro, fueran o no a Frankfurt, sincronizaban miras en dirección hacia Europa. El fugaz y quizás intrascendente acontecimiento que enfrentó al joven editor ignoto y a los principales promotores de la exposición argentina en la Feria de Frankfurt, puede ser recuperado como manifestación y desestabilización de una estructura decisiva para pensar los contornos de la producción cultural contemporánea. 
La elección de un país como invitado de honor de la feria del Libro de Frankfurt acentúa las disputas internas de un campo editorial nacional (la divergencia de sus intereses, sus líneas de fuerza, sus puntos de apoyo colectivo, etc.) y pone en evidencia el tenor de las relaciones entre los editores y el Estado. La postulación de un país decanta de gestiones promovidas por los agentes más dinámicos en Frankfurt, editores que así devienen "representantes" de un mercado nacional. Se trata, por lo general, de los que participan hace más tiempo y ocupan posiciones político-sectoriales que los disponen a un contacto frecuente con los organizadores alemanes. Pero la aceptación de una nación la deciden estos últimos, sólo cuando el Estado del país postulado y elegido firma un contrato que asegura financiamiento y representatividad oficial. Un evento entre empresarios culturales rubricado por Ministros de Relaciones Exteriores. La organización de la Exposición de la Argentina como país invitado de honor en la feria de Frankfurt 2010, estuvo a cargo de una entidad ad hoc denominada Comité Frankfurt (Cofra), bajo dependencia del Ministerio de Relaciones Exteriores ${ }^{1}$. La misma fue el producto de las negociaciones iniciadas por los editores y proseguidas por el Estado nacional.

Entrelos editores participaban representantes de dos cámaras: la Cámara Argentina del Libro (CAL) y la Cámara Argentina de Publicaciones (CAP) ${ }^{2}$. Algunas diferencias entre la CAL y la CAP permiten revelar tensores estructurales de cualquier campo editorial periférico, en la era de la "globalización". La CAL es la institución gremial de los editores argentinos desde 1938. Nació en paralelo a la Sociedad de Escritores. La CAP fue fundada en 1970 y abarca no sólo a editores de libros sino también a algunos productores de revistas para el gran público. Este perfil se reconoce en una más nítida caracterización como cámara de empresarios. Por ello atrajo la filiación de las grandes empresas de libros didácticos, cadenas de librerías y principales distribuidores. No sorprendió que fuera la institución que cobijara a los grupos trasnacionales que desde los años 80 adquirieron casi todos los sellos editoriales más dinámicos, tradicionales, reconocidos de la Argentina (Estrada, Kapelusz, Sudamericana, Emecé, Paidós, etc.) ${ }^{3}$. Este sólo efecto hizo que la CAL se viera a sí misma como territorio si no de "editores

\footnotetext{
1 En Sorá (2011) estudio algunos aspectos de la génesis de la elección de la Argentina como país invitado de honor de la Feria de Frankfurt 2010.

2 La CAP demostró interés y oficializó su participación tardíamente, el año de la exposición. La CAL trabajó más intensamente en la génesis del evento y utilizó la organización y realización como una instancia para legitimarse ante el Estado y el mercado internacional como la auténtica entidad gremial de los editores argentinos. Carlos dos Santos, editor-fundador de Manantial, una editorial mediana de ciencias sociales y humanas, era Presidente de la CAL hacia octubre de 2010 y fue el único representante de los editores argentinos que habló en la ceremonia inaugural de la feria alemana.

3 José Luís de Diego (2012) desarrolla un estudio sobre el proceso de concentración económica sufrido en el campo de la edición Argentina en los últimos 30 años.
} 
independientes", al menos como institución político-cultural de resistencia, de lo nacional, del oficio genuino. En consecuencia, desde el año 2000 aproximadamente, la CAL es objeto de interés y participación de editoriales pequeñas y medianas que posiblemente no se hubieran interesado en la filiación y acción gremial cuando esa entidad era dominada por apellidos emblemáticos de la edición argentina: Kraft, Zamora, Losada, García, Klasse, Del Carril, etc. Esta dinámica de reestructuración institucional de la edición, efecto de la concentración financiera y del cambio de reglas del mercado editorial que trajo aparejado, tuvo su manifestación a escala continental: el Grupo Interamericano de Editores (GIE) fue una institución empresarial supranacional que desde 1978 promocionó, entre muchas otras acciones, la participación de editores latinoamericanos en instancias de decisión mundiales como la Unión Internacional de Editores. Según Alfredo Weizsflog, figura emblemática de la Cámara Brasileira do Livro y del GIE, esta asociación fue "detonada por los grupos españoles", hacia fines de la década de 1990, en una acción de desprestigio iniciada desde Santillana-Colombia ${ }^{4}$. Los grupos impusieron el cambio de denominación del Grupo: de inter-americano a iberoamericano.

Lo que llamé tensores estructurales, y es superficialmente revelado por los cambios en los marcos institucionales de la edición en la Argentina, es sintetizable en un par binario axial: grupos concentrados - editores independientes. Alrededor del mismo se organiza un sistema de oposiciones complementarias: trasnacional - regional, uniformidad - diversidad, economía - cultura, global - local, etc. Esta estructura es a su vez la transformación de oposiciones anteriores y se corresponde con otras homólogas en distintas lenguas y latitudes. Todo pasa como si en los mercados editoriales (y las industrias culturales en general) se hubieran acentuado de manera liminal las diferencias entre los polos de la gran producción y de la pequeña producción ${ }^{5}$. Esta condición explicaría la manera como se han tornado visibles formas

4 Entrevista a Alfredo Weizsflog durante la Feria de Frankfurt en octubre de 2011. Es decisivo pensar que Weiszflog o Del Carril, no eran editores independientes, tal como lo denotado por esta reciente forma de clasificación de las prácticas y posiciones editoriales. Weiszflog es heredero del Grupo Melhoramentos (São Paulo), emporio industrial de empresas ligadas al papel (su slogan es "do pinheiro ao livro"). Del Carril, era el ex presidente de la editorial Emecé, empresa de edición "generalista" de gran porte que en su catálogo disponía desde poderosos best sellers (p.e.: Wilbur Smith) hasta autores centrales del canon nacional (Borges) y universal. Melhoramentos resistió a la fusión con grandes empresas trasnacionales, mientras que Emecé fue comprada por Bertelsmann en 1999. Esta mirada histórica es decisiva para comprender cabalmente las transformaciones a partir de las cuales se estructura la oposición del presente entre grupos concentrados y editoriales independientes.

5 La definición de una oposición entre grande y pequeño alude al problema factual del peso que tuvieron en los últimos veinte años los capitales económicos en la organización de los mercados de bienes simbólicos. Esta hipótesis invita a un minucioso debate sobre las relaciones entre esta oposición y la definida por Pierre Bourdieu entre los polos de la edición para el gran público y la edición restringida. Ésta sería más global, trascendente y de más larga duración histórica. Sin embargo, parece no ser suficiente para cualificar las singularidades del actual esquema de oposiciones. 
de acción otrora insignificantes, como la "edición independiente", sobre la cual años atrás se podría haber dicho con extrañamiento: ¿independiente? ¿de qué? ¿de quienes? En Argentina y en buena parte de occidente, la conformación de grupos editoriales desestabilizó la estructura previa del sistema editorial, basado en emprendimientos relativamente autónomos, con fuerte predominio del componente familiar de las empresas. Este fenómeno puso en jaque a todas las instancias de producción cultural y provocó cierre de empresas y comercios de cultura. Hacia 2001, esta crisis específica (del sector editorial) se sincronizó con la demoledora crisis política, económica y social argentina. Al calor de asambleas cívicas y del aferramiento a la cultura como una alternativa de "salvación" colectiva, surgieron centenares de emprendimientos culturales de pequeña escala ${ }^{6}$. Sería preciso un estudio para establecer el alcance de las tasas de muerte y de nacimiento de editoriales que se observó entre 1995 y 2005.

¿Cómo son las editoriales surgidas en los últimos diez años? Algunas guardan semejanza formal con la edición tradicional: dedicación exclusiva a las tareas editoriales, tendencia a una división de funciones, aún cuando puedan ser empresas de muy pequeña escala ( 3 o 4 personas), cultivo de un catálogo y prácticas tradicionales como la pretensión de exponer en ferias, promover la reseña de sus libros en periódicos, etc. Pero muchos proyectos trasbordan las definiciones standard del métier. Desafiando los supuestos de la evolución de la cultura occidental, nunca parece haber sido tan sobre-representada la edición de autor y se solapan categorías que la historia desgajó unas de otras. Vuelven a aparecer personas o colectivos que pueden encarnar en un mismo tiempo y lugar a autores (artistas) - editores - impresores distribuidores - libreros - traductores. Las combinatorias que se pueden dar entre algunas de estas funciones alternativas son efecto tanto de lo que la concentración financiera arrojó al margen, como de las posibilidades de comunicación abiertas por las transformaciones tecnológico-digitales, de acceso relativamente sencillo y a bajo costo. En aparente paradoja, estos editores del presente juegan con la marginalidad y con el poder. Son un signo visible, reconocido (también estudiado); sus actores reclaman derecho a existir, a tener representatividad.

\footnotetext{
No toda editorial que no pertenece a un grupo de empresas editoriales observa necesariamente las características de una editorial de vanguardia cultural. Al mismo tiempo no toda editorial de pequeño o mediano porte (que no pertenece a un grupo concentrado) se identifica como "independiente". No será este texto el espacio para dirimir un esquema teórico indispensable para comprender los capitales en disputa en la producción editorial contemporánea. Decanta de estas observaciones la necesidad de complementar las dimensiones objetivas y subjetivas que se moldean en las prácticas editoriales concretas de la diversidad de agentes que puede existir en un espacio de producción situado en coordenadas de espacios y tiempos, específicos y homologables.

6 Winik (2010), Vulponi (2012) y Ruibal (2012) son algunas de las referencias entre los numerosas investigaciones en curso que retratan esa profusión de actividades literarias y editoriales en la Argentina de los últimos 10 años.
} 
No fue casual pues, que un grupo de 40 editores "independientes" organizara una feria de libros al interior de la Biblioteca Nacional, en Buenos Aires, en 2009. Elnombre del evento, "Rumbo a Frankfurt", denotaba el alcance de su pretensión. Para alcanzar la deseada meta, propusieron una secuencia de actividades para instituir alguna alternativa colectiva, política, para encausar ciertos intereses singulares. Ninguno de ellos, efectivamente, parece contar con condiciones de "vender y comprar" en una feria internacional de libros. Sin embargo, la clase de proyectos culturales-políticos que suelen encarnar se orientan a un espacio internacional, como si fuera indispensable "hacer alianza" con emprendedores homólogos (contra-culturales, independientes y tantas otras formas en que ellos se adscriben) de otras latitudes. El objetivo de aquella feria en la BN fue hacerse escuchar y articular discursos y acciones para enfrentar a los poderes que dominan la edición nacional e internacional. Promovieron a partir de entonces un estado de debate permanente sobre la crisis de la cultura global y la misión de los editores independientes. Las jornadas fueron inauguradas por Horacio González, Director de la BN, renombrado filósofo e intelectual orgánico del gobierno nacional. Como resultado de sus demandas para estar presentes en Frankfurt, se derivó a "los independientes" a continuar gestiones en la Cancillería, a través de la Cofra. Allí los habrían recibido correctamente. Los editores alimentaron ilusiones. Poco después los contactaron de la Cofra para notas de prensa con medios alemanes y nacionales que comenzaban a promover la exposición argentina. Las ilusiones aumentaron: “Cuando nos llamaron de la Cancillería para 'conversar' nos preguntaron 'para qué querríamos ir a Frankfurt, si nada teníamos para vender, si no usábamos copyright'. Nosotros respondimos: 'Nosotros tenemos que ir, es muy importante!” (Winik, 2012, p. 7). La política oficial no sólo descuidó a los pequeños editores. Los recursos del Estado se destinaron masivamente a los escritores, los intelectuales, la literatura, es decir, a las figuras tradicionalmente consagradas como encarnación del genio de un pueblo. Para los editores (de cualquier tipo) no hubo financiamientos. Sólo se contribuyó con el stand colectivo, espacio que fue objeto de fuertes críticas por cierto descuido estético y organizativo, además del lugar marginal en el que estaba localizado, hacia la porción menos visitada de un pabellón alejado de las zonas de mayor tránsito en la Feria de Frankfurt. Más allá de quejas aireadas o subterráneas, los editores quedaron satisfechos con el Programa Sur, el que por primera vez pasó a subvencionar la traducción de autores argentinos en el extranjero ${ }^{7}$.

7 En Dujovne y Sorá (2010), estudiamos la significación que tuvo la acción del Estado en la exposición de la Argentina como país invitado de honor de la Feria de Frankfurt, en cuanto hecho prácticamente inédito en la historia de la cultura nacional. Desde un punto de vista comparativo, a escala iberoamericana, es posible afirmar que una de las singularidades del caso argentino es que se trata de un mercado editorial que ha evolucionado, a lo largo del siglo XX, prácticamente sin apoyos estatales. 
Un año después de la feria de editores independientes en la Biblioteca Nacional, la irrupción de Matías Reck en el evento oficial de la feria de Buenos Aires, al que me referí al inicio, fue una provocación racionalmente orientada a incomodar a autoridades y a cuestionar un modo de negociar los rumbos de la cultura dominante. Él ya sabía que ellos quedaban excluidos del mega-evento. No tenía nada que perder. Mochila, barba y pelo largo, vestimenta, posturas, discurso "contra-culturales". Parecía una anécdota sin consecuencias, un toque de color local en un evento promocionado por extranjeros y de intenso interés oficial ¿Una espina en el zapato?

Vi aquél "joven" durante el inicio de mi trabajo etnográfico en la Feria de Buenos Aires (abril de 2010). Lo volví a ver en Frankfurt (octubre). Para el stablishment, Matías Reck allí fue más incómodo aún: ocupó un stand, o mejor dicho, según su lenguaje, okupó un stand en plena feria de Frankfurt, casi en frente del stand colectivo de la Argentina. ¿Qué hacía allí? ¿Qué hizo? ¿Cómo es posible qué la Feria de Frankfurt de lugar a esta clase de expresiones? ¿Fue una singularidad "argentina” o "latinoamericana” ¿Qué hechos de alcance general explica su aparente anomalía? Para encausar estos interrogantes es necesario observar y comprender su lugar entre la diversidad de editores que es capaz de hacerse presente en la superficie de la feria de Frankfurt. Ante la amplitud de este objetivo y a la luz del caso enfocado, apelaré al registro fotográfico (producto de mi trabajo de campo etnográfico en 2010 y 2011 ) $^{8}$ como disparador y síntesis para esbozar cierta tipología de expositores. El objetivo, como se desprende de mis hipótesis, es demostrar lo que une a toda suerte de editor entre grandes grupos y pequeños emprendimientos vanguardistas. Nada mejor que una feria, espacio que, por sus características de ritual, atrae a todos. Frankfurt compele a dar la cara en ese lugar donde la evolución del mundo del libro parece jugarse o ponerse a prueba anualmente. Aún los que no pueden ir y lo justifican como si "no fuera para ellos”, no son indiferentes a tal acontecimiento. Y de entre estos cada año se desprende un sector de agentes que van, contra viento y marea, para ver, aprender, conectarse. Es por ello que sobre la superficie de la feria es posible observar una amplia diversidad de tipos de participantes. Al ir, los nuevos salen transformados y su pasaje por Frankfurt sedimenta un entramado de oposiciones que permite concluir que la diversidad no corre, por ahora, riesgos de extinción. Me interesa pensar lo que une y separa a la pequeña y a la gran edición. Por ejemplo, a la editorial de Matías Reck, Milena Caserola, y al Grupo Planeta. En un límite (estructural), uno no se entiende sin el otro?.

8 Estas fases de trabajo de campo fueron realizadas junto a Alejandro Dujovne. En 2011, nuestra labor fue parcialmente financiada por "Mondédition. Socio-histoire des foires internationales du livre depuis 1945", proyecto de investigación coordinado por Hervé Serry, en el marco del Programme d'aide à la recherche innovante 2010-2012, de la Université Paris 8.

9 La indispensable crítica al neoliberalismo tiene como aspecto negativo una visión en blanco 


\section{ESTAR ALLÍ: LA FERIA DE FRANKFURT, UN LUGAR DIVERSO}

La feria de Frankfurt es inmensa, en comparación a otras ferias del género en cualquier latitud. Sus estructuras edilicias, su burocracia organizativa, su transformación permanente le aseguran la prevalencia mundial desde finales de los años 1950. Bajo tales dimensiones, ¿dónde estaba Reck? ¿Por qué esta clase de editores siente qué es tan importante llegar a Frankfurt? ¿Dónde puede estar un editor independiente en la principal feria del mundo? ¿Cómo? ¿Qué hacen allí como diminuta presencia frente a los grandes grupos que dominan la feria y la edición actual?

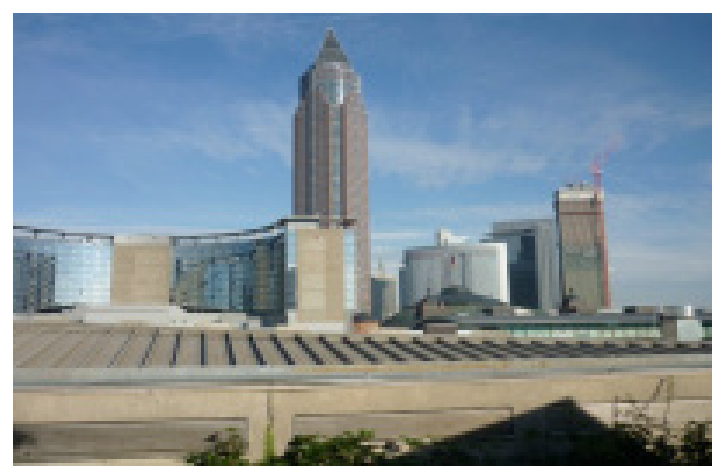

IMAGEN 1.

y negro de las realidades polares como la aquí enfocada para el caso de la edición. Esto puede verificarse en el habitual desequilibrio con que las ciencias sociales se lanzan al estudio de los dominados (en este caso los editores independientes) y el desinterés por estudiar con igual énfasis y detalle a los dominantes (grupos editoriales). Bajo un principio relacional que se centre en problemas de interdependencia y correlación entre los polos antagónicos, se impone la ampliación de toda suerte de observaciones de tenor etnográfico, para relevar realidades, permitir comparaciones y ampliar las capacidades de generalización. 


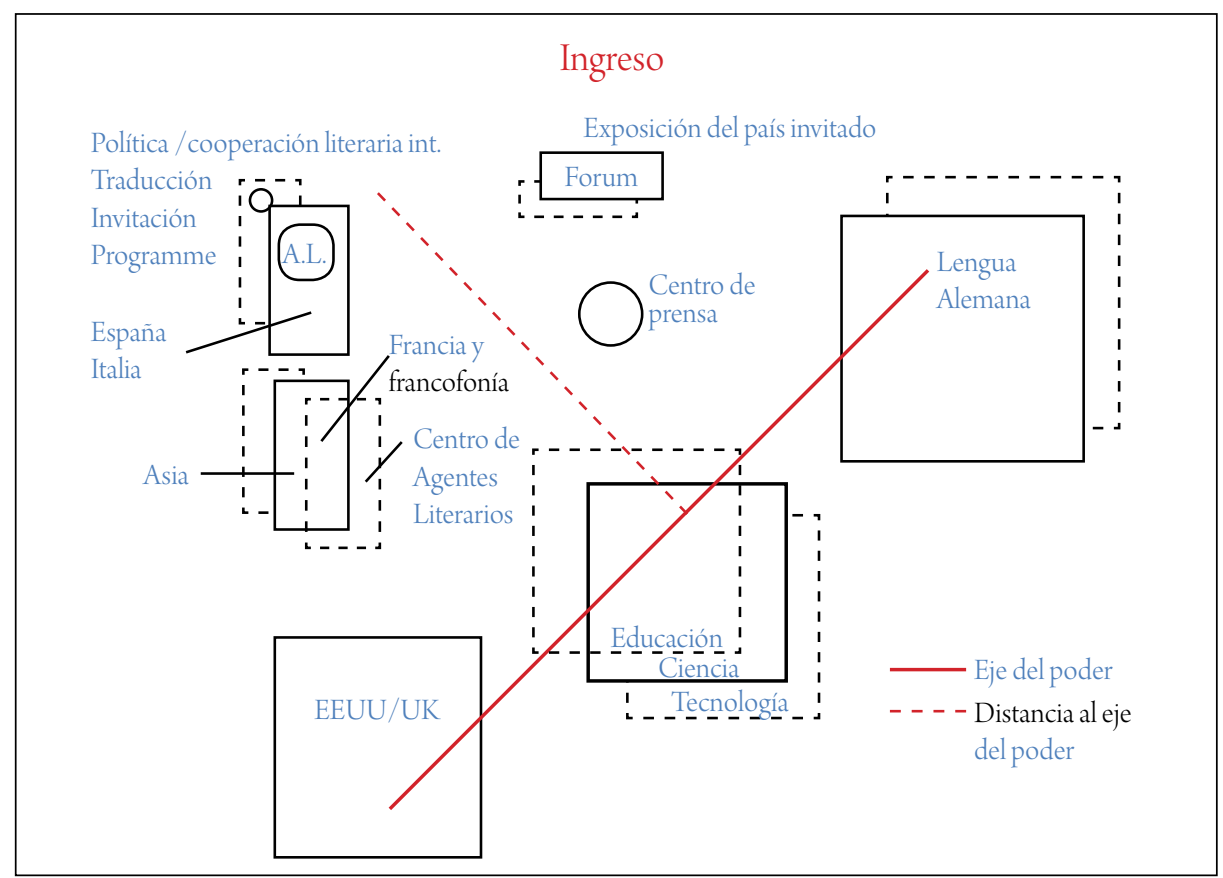

FIGURA 1.

En este boceto del plano de la feria, con línea (roja) continua marco lo que con Alejandro Dujovne denominamos "eje del poder económico" (Dujovne y Sorá, 2010, p. 221). Es una transecta que evidencia la mayor densidad del tránsito humano y de los intercambios profesionales, entre los pabellones 3 (lengua alemana) y 8 (lengua inglesa). No es un factor al azar que entre esos pabellones intermedie el 4, pabellón multinacional y multilingüístico que aloja la edición de libros didácticos, de arte y científicos, junto a las empresas de tecnología. Es decir, algunos de los sectores más dinámicos en términos financieros y en vanguardia para las innovaciones técnicas. Francia (lengua francesa) y Asia oriental, por ejemplo, exponen en el Pabellón 6, piso 1 (6.1), mientras que los editores latinoamericanos exponen en el nivel 5.1, "más atrás", según la distancia al poder económico que objetiva la línea punteada. Este piso, a su vez, es precedido por España e Italia que abarcan la mitad de la superficie de la planta 5.1 y en posición anterior, o espacialmente más cercana al eje del poder. Si también se considera la oposición arriba / abajo, vemos que en un vértice del piso inferior del pabellón 5 (o sector 5.0), abajo de América Latina, se forma un rincón "político" de la Feria, donde los organizadores alojan a los editores promisorios de Asia, África y América Latina, que reciben con su Invitation Programme. En ese rincón hay un foro de debate sobre traducción y otro sobre asuntos políticos. Allí también promocionan sus labores algunas instituciones de lo que podríamos llamar cooperación literaria o 
cultural internacional ${ }^{10}$. Podemos considerar que este extremo de la línea punteada demarca un polo político mientras que su opuesto demarca un polo económico.

Los tipos de expositores se pueden diferenciar por la desigual distribución de recursos de visibilidad. Los grandes grupos montan stands en amplios espacios con tecnologías publicitarias acordes a sus objetivos: hacerse notar como gestores del mayor número posible de sellos, es decir como grupos reconocibles por su poder económico:

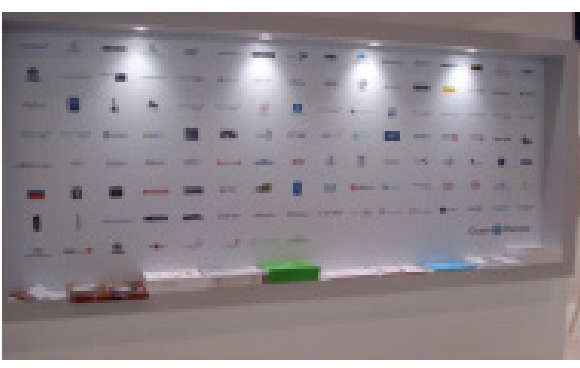

IMAGEN 2.

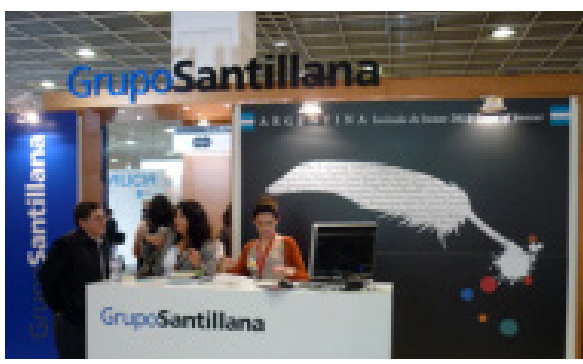

IMAGEN 4.

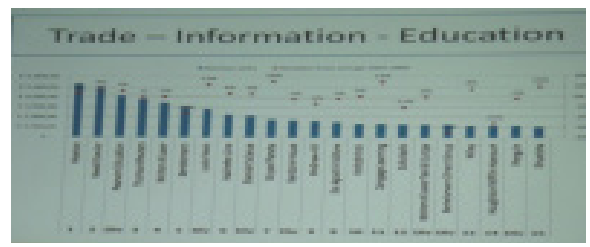

IMAGEN 3.

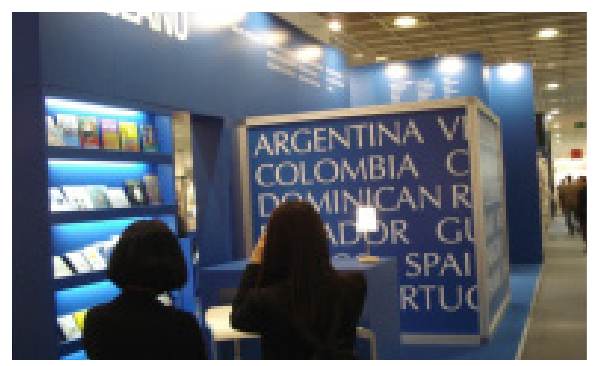

IMAGEN 5.

La "marca" de estos expositores es el conjunto de sellos que forman parte de cada grupo (imagen 2 - stand de Planeta). El reconocimiento está ligado a la cantidad de editoriales absorbidas y el volumen global de facturación, lo que las pone en competición con grupos del mismo perfil que periódicamente miden sus poderes en eventos, realizados al interior de la feria, cuyo objetivo se resume en rankings económicos (imagen 3). Sus stands se caracterizan por la impersonalidad de la atención (imagen 4) y la cantidad de mesas para recepción de clientes (compra yventa

10 Por ejemplo, la Sociedad para la promoción de las literaturas de Asia, África y América Latina, organización alemana creada en 1980, entre otros por Peter Weidhaas. 
de derechos) que son capaces de disponer. Allí no hay signos de filiación nacional sino de posicionamiento global, representado por la suma de los mercados adónde se extiende su área de actividad (imagen 5). A pesar de estas características, los stands centrales de estos grupos están en las áreas de sus países de origen. En los casos de países con mercados editoriales fuertes, como España, Italia o Francia, los stands de los grandes grupos son tan o más grandes y concurridos que los de las instituciones sectoriales nacionales. En el sector anglosajón, en el otro extremo, los stands de las asociaciones de editores norteamericanos o ingleses son un punto insignificante (situados en los bordes, sin decoración, casi sin visita de públicos, apenas como lugares de apoyo técnico), en un océano de stands de gran tamaño pertenecientes a grupos empresariales. Por el contrario, en los espacios de países dominados como los latinoamericanos, los stands colectivos de las cámaras o gremios nacionales son el todo: bajo su representación exponen prácticamente todos los editores de esos mercados. Sólo excepcionalmente algún editor (o grupo) brasileño, argentino o mexicano llega a tener un espacio de exhibición individual, aparte del stand "oficial". En síntesis, podría decirse que a mayor dominación de un mercado nacional, mayor diferenciación e individualización de sus expositores, mientras que cuanto más dominado es un mercado más colectiva y naciocéntricamente se expresan las exhibiciones. En este polo la nación es un signo más evidente, un clasificador inexorable para sus agentes.

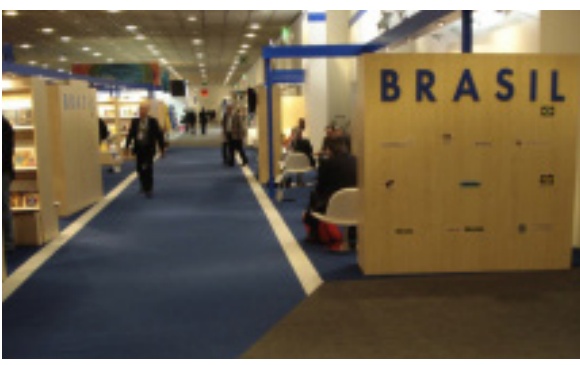

IMAGEN 6.

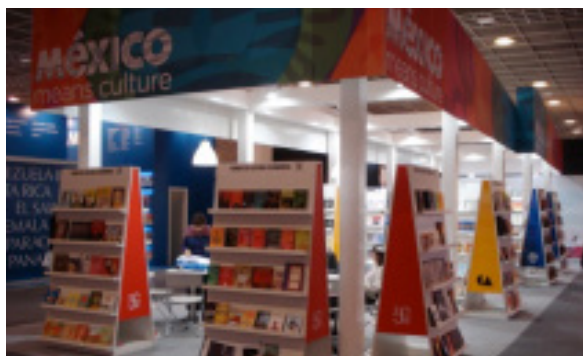

IMAGEN 8.

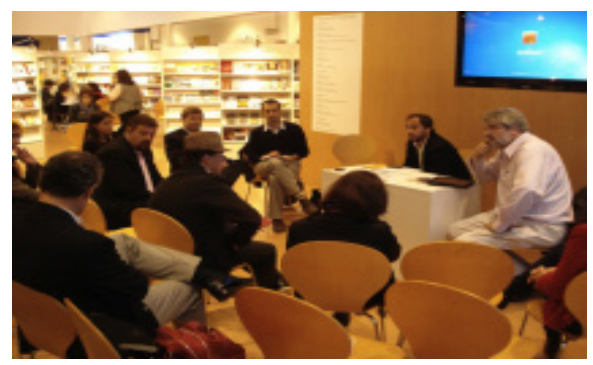

IMAGEN 7.

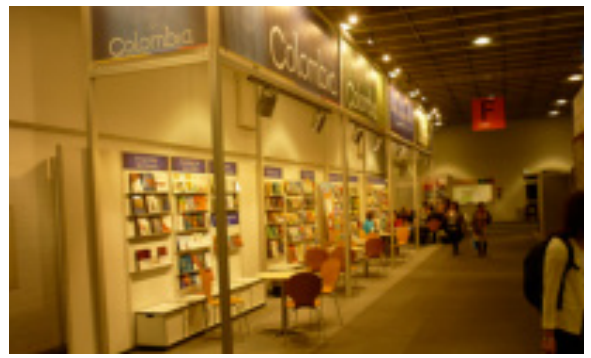

IMAGEN 9. 


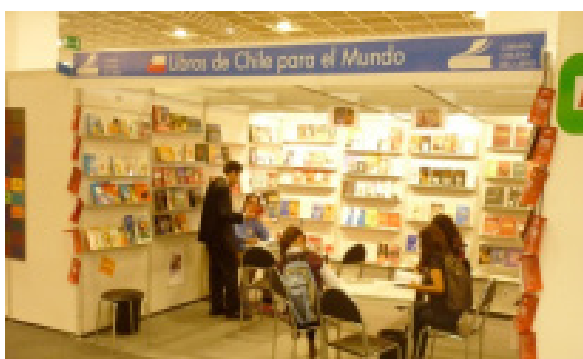

IMAGEN 10.

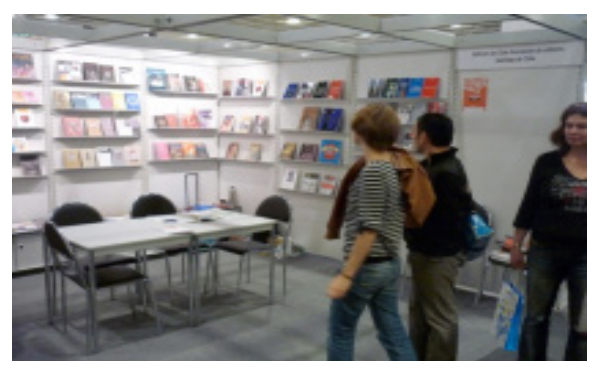

IMAGEN 11.

Veamos algunas marcas de la exposición de los editores de América Latina. La materialidad de los stands y su superficial aprehensión visual son elocuentes sobre los desiguales poderes. Del Brasil o México se pueden encontrar pequeños stands "aparte" del Grupo Record y Companhia das Letras, por un lado, y del Fondo de Cultura Económica, por el otro. Chile, por ejemplo, es representado por dos stands institucionales. Por un lado el de la Cámara Chilena del Libro (imagen 10) y por el otro el de la Asociación de Editores de Chile (imagen 11), escisión promovida por LOM y otros editores independientes, cuando la entidad gremial tradicional fue dominada por grupos económicos trasnacionales (Symmes, 2009; Symmes, 2012).

Mis observaciones se concentraron en los editores argentinos y por ello dedicaré atención a sus maneras de estar en Frankfurt como medio para abarcar problemas de alcance general. El stand argentino es montado por la Cámara Argentina del Libro (CAL), en cuanto que los sellos tradicionales de la Argentina adquiridos por los grupos extranjeros (Emecé, Sudamericana, Paidós, etc.) aparecen diluidos en los stands de sus grupos empresarios, mayoritariamente en "territorio español". Es decir, en el stand "argentino" predominan editoriales independientes de diverso género, en muchos casos de poca antigüedad relativa. En los dos años de observación y como significativa novedad, también se observa una creciente presencia de editoriales universitarias ${ }^{11}$. Otros editores van a Frankfurt sin stand y sin apoyatura en el marco de representación de la Cámara. El editor Alejandro Katz, por ejemplo, es el único caso de un editor independiente filiado a la CAP y no a la CAL. Eso explica parcialmente que vaya a Frankfurt sin el "paraguas" de la CAL. Pero al mismo tiempo es una prestigiosa editorial de "traducciones" de humanidades y ciencias sociales, creada en

11 Entre éstas se destacan las editoriales y editores que dominan la REUN, Red de editoriales universitarias de la Argentina. Estas editoriales son las de las Universidades de Villa María, de Quilmes, de General Sarmiento y del Litoral. A estas se suma, aunque con cierta autonomía, la editorial de la Universidad de Buenos Aires y de universidades de poca antigüedad, del "conurbano" de la ciudad de Buenos Aires. 
2006. Su editor-fundador camina la feria sin libros propios para exhibir y vender. $\mathrm{Si}$ no se lo conoce, no se lo ve. Katz nació internacionalizada, como editorial con sede en Buenos Aires y escritorio en Madrid. Rápidamente granjeó reconocimiento entre intelectuales y académicos, en el dominio específico de las humanidades. Su agenda en Frankfurt es concreta, certera y puntual, como uno más entre los agentes para los cuales Frankfurt está hecha a su medida. Adriana Hidalgo, por su lado, es una editorial homóloga a Katz en el terreno de la literatura. Ellos sí representan a algunos escritores consagrados o de vanguardia latinoamericanos ${ }^{12}$. Tienen para "vender y comprar". Aunque no son una editorial de porte, como Companhia das Letras, como para sustentar un stand individual, a pesar de que el precio del $\mathrm{mt} 2$ de stand es más barato que en la Feria de Buenos Aires. La estrategia de Adriana Hidalgo es potenciar su catálogo, su estilo, en sociedad con cinco editoriales europeas de similar perfil. Juntas tienen un stand en el centro del pabellón 5.1. Su proyecto estético busca trascender la clasificación nacional. Si tomamos en cuenta su exposición relativamente distante de otros editores connacionales, podemos decir que las apuestas de Katz o Adriana Hidalgo extreman la diferenciación y se orientan en sentido más universal y en cierta medida desterritorializado.

\section{VARIANTE ALEMANA DE LAS POLÍTICAS INTERNACIONALES POR LA DIVERSIDAD EDITORIAL}

Como vemos, Frankfurt puede ser definida como una feria con múltiples ferias en su interior, cada una de ellas condicionada por la totalidad del sistema. La disposición de los pabellones y de cada piso al interior de cada pabellón (6 pabellones con varios pisos cada uno) no es el resultado de un plan racional que decanta de un estudio de los diversos recursos con los que participan los agentes de cada mercado o área lingüística. Cada configuración resulta de la larga historia de participación de los agentes individuales y colectivos, de sus relaciones de fuerza en los campos (regionales, nacionales, lingüísticos, etc.) que los reúnen de manera objetiva, y de negociaciones específicas entre editores y con la AuM, para hacerse un lugar en la Feria. Al mismo tiempo la distribución de los agentes intenta ser controlada por directivas de la AuM. Si bien la institución organizadora de la feria no puede regular

\footnotetext{
12 La historia de la editorial Adriana Hidalgo es muy interesante para pensar las transformaciones del mercado editorial y del oficio editor. Esta editorial lleva el nombre de su fundadora y fue creada en 1999 con los recursos que Adriana recibió con la venta de la editorial y librería El Ateneo, por ser nieta de los hermanos García, propietarios-fundadores de aquella firma. La heredera de una editorial y librería de gran tamaño en la Argentina reinvierte en el mundo editorial en un proyecto autónomo, y desplazando hacia un polo de prestigio cultural la huella de una empresa de porte adquirida por un grupo financiero.
} 
completamente el lugar que logra cada empresa o institución, al menos diseña para cada piso lugares específicos para canalizar lo que ellos observan como problemas de interés significativo para las comunidades de agentes de cada sector.

La AuM depende de la Cámara de libreros y editores alemanas. Se organiza en una presidencia y en un directorio de 5 personas, cada una representante de los vínculos con una región del globo. Cada sección mantiene permanente relación con editores de las regiones en las que actúa. Se realizan estudios, informes, vínculos de trabajo, de amistad, se aprehenden percepciones y un conocimiento detallado a través de viajes continuos, que también comprenden la realización de exposiciones de libros alemanes en ferias del extranjero. Resulta de ello un seguimiento de cada región y la creación de espacios, eventos, políticas para dinamizar la presencia de los editores de cada una, en función de sus demandas, características y potencialidades. Es significativo que el piso 1 del pabellón 5, donde expone la edición iberoamericana e Italiana ${ }^{13}$, sea el elegido para acoger un espacio de expresión de la "edición independiente" (imágenes 12 a 17). Esta categoría, como vemos, se manifiesta hacia el polo político del espacio de poder objetivado en la feria de Frankfurt. En 2010 allíse expusieron libros de editores independientes alemanes y argentinos, en un proyecto denominado Hot List (imágenes 12, 13, 15) ${ }^{14}$. El diálogo privilegiado entre estos agentes se expandió en foros de discusión (imagen 17), así como en mesas redondas, en las que se comunicaron experiencias, estados del sector, dilemas y perspectivas, en las que se reforzó el interés y la necesidad de orientar las acciones en sentido colectivo e internacional. Estas reuniones pueden ser abiertas al público (imagen 16) o cerradas, tal como evidencia la imagen 15 , que muestra a editores independientes de varios países de América Latina en diálogo con Dieter Schmidt, segundo responsable de la AuM para América Latina.

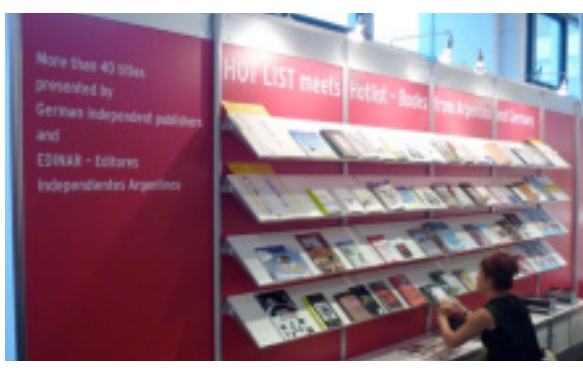

IMAGEN 12.

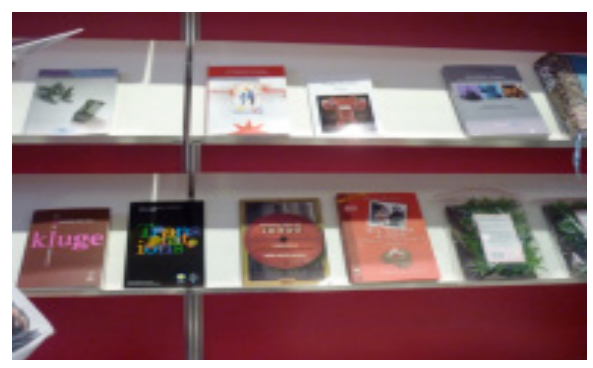

IMAGEN 13.

13 En el Pabellón 5.1, también están los stands de otros países "mediterráneos", como Grecia y Turquía, así como los países balcánicos.

$14 \mathrm{Al}$ año siguiente (imagen 14) ese espacio se amplió para editores independientes de Iberoamérica, bajo el lema Otra Mirada. 


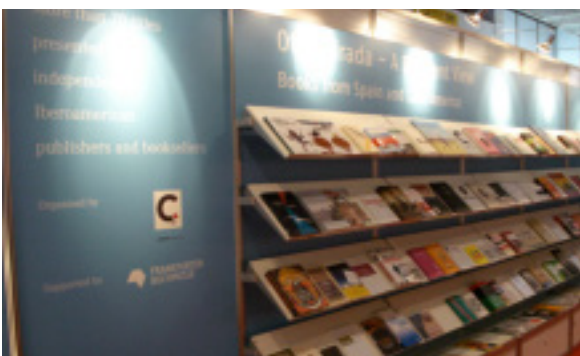

IMAGEN 14.

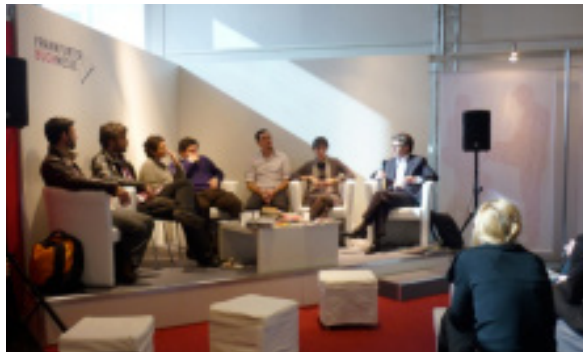

IMAGEN 16.

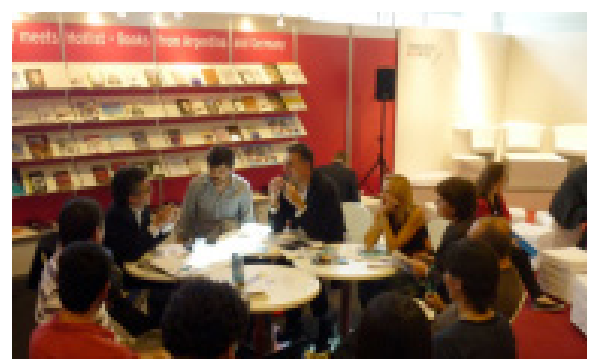

IMAGEN 15.

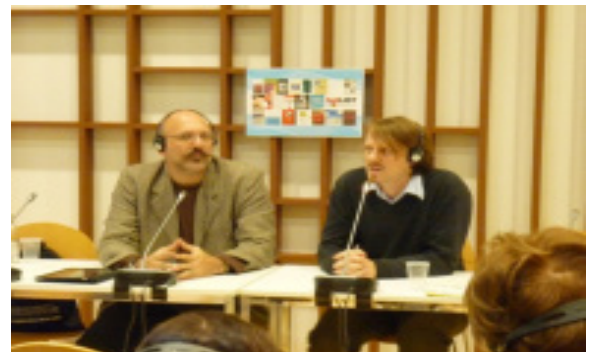

IMAGEN 17.

Lo que me interesa remarcar es que la Feria de Frankfurt (también) aparece como un lugar deseable para editores de pequeños emprendimientos, aún cuando no tengan casi nada para negociar. ¿Contradice esto la caracterización corriente de Frankfurt como una "feria de compra y venta de derechos"? El argumento que predomina cuando se le pregunta a los pequeños editores por las razones de su presencia, se centra en una cuestión pedagógica: aprender, lo cual puede querer decir aprender para conocer tendencias, conectarse, renovarse, para crecer, etc. En el caso de los editores independientes la intensión también se orienta a la asociación colectiva para planificar políticas e instituciones que permitan lograr de manera colectiva lo que ningún caso singular alcanzaría de modo individual.

El reconocimiento de una feria alemana como la principal del mundo, se sustenta, en parte, a través de estratégicas políticas culturales para diferenciarse de la mercantilización de las prácticas que predomina en la avasallante fuerza de la edición anglosajona. Si para los editores ingleses y norteamericanos no tiene sentido hacer exhibiciones de culturas nacionales en un evento de negocios (Inglaterra y Estados Unidos nunca fueron países tema y difícilmente lo sean algún día), para los alemanes o franceses, poco podría lograrse sin anteponer alguna razón de política cultural en tanto que países baluartes desde donde baja (o se difunde en escala planetaria) la cuestión de "la diversidad". La presencia de editores diversos fue un objetivo alimentado por Peter Weidhaas, en su larga gestión como Director de la Feria entre 1974 y 2003 . Entre otras acciones para contrarrestar lo que él llamó el peligro de la 
bestsellerización de Frankfurt, se pueden mencionar la organización de temas focales “tercermundistas" (1976 - 1986), luego de países invitados de honor (desde 1988)15. También el ofrecimiento anual de becas e invitaciones a la feria para pequeños editores promisorios de mercados dominados en la escena global.

Es posible afirmar que la feria de Frankfurt ha sido (y es) central en la historia de la política cultural que transformó el lugar de Alemania en el escenario internacional después de la segunda guerra mundial. Las acciones de promoción de la diversidad cultural son generalmente financiadas con fondos del Ministerio de Relaciones Exteriores. Esta variante nacional de las políticas por la diversidad que giran alrededor de la Unesco (Bustamante y Symmes, 2013), permiten comprender por qué en ciertos años se incrementa notablemente la aparición de agentes independientes y de América Latina, en la Feria de Frankfurt. Este fue el caso de 2010, cuando la Argentina fue país invitado de honor. Fue llamativo que muchos editores independientes de todo el continente fueron a esa versión de la feria. Para esa ocasión, los independientes de Iberoamérica organizaron una cadena de encuentros previos y posteriores a la feria, y centralmente durante la misma: en Buenos Aires, en Madrid, en Frankfurt, en París, en Guadalajara, generalmente en el marco de ferias internacionales, como demostrando que no son un hecho marginal, que pretenden imponer su diferencia en el seno del poder. Ya en 2011, la presencia de editores independientes de América Latina en la feria de Frankfurt disminuyó significativamente.

\section{UN LUGAR DESEABLE}

Entre los editores “independientes” presentes en Frankfurt 2010 y provenientes de la Argentina se puede diferenciar un grupo de trayectorias que reúne a "ex fellows" de la Feria, como Carlos Díaz (Siglo XXI - imagen 18, mesa de atrás), Leopoldo y Octavio Kulesz (Libros del Zorzal) o Gabriela Adamo (Fundación Typa y actualmente directora de la Feria de Buenos Aires). Desde que fueron becarios de la feria, intentan ir todos los años. Ellos sienten que conocen lo que significa la feria como pocos. Son jóvenes y, tras la iniciación en Frankfurt, cultivan una ética profesional e internacionalizada. Se identifican con Frankfurt, manejan bien sus códigos, saben con quiénes hablar, adónde ir, como orientarse. Se observan otros editores que inician parcialmente esos trayectos, al ser escogidos por el Invitation Programme. En 2010 fue el caso de Guillermo Höhn de la editorial Pictus (imagen 21 - fondo de escena).

15 Sobre Peter Weidhaas y su relación con AL, véase Sorá (2011). Weidhaas dejó plasmada "su historia" de la feria de Frankfurt en tres libros: Weidhaas (1999, 2007, 2010). 


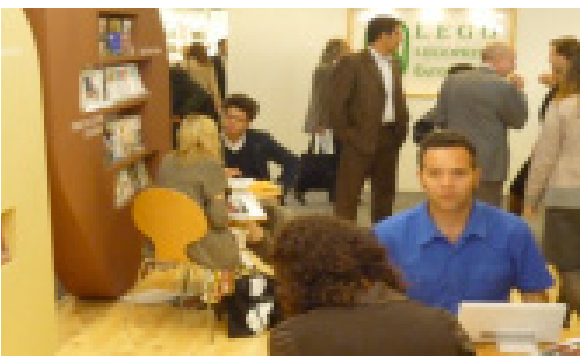

IMAGEN 18.

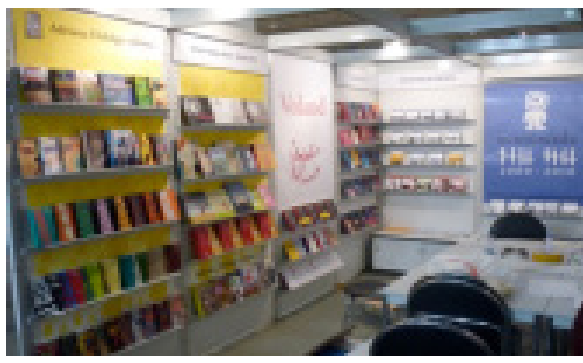

IMAGEN 20.

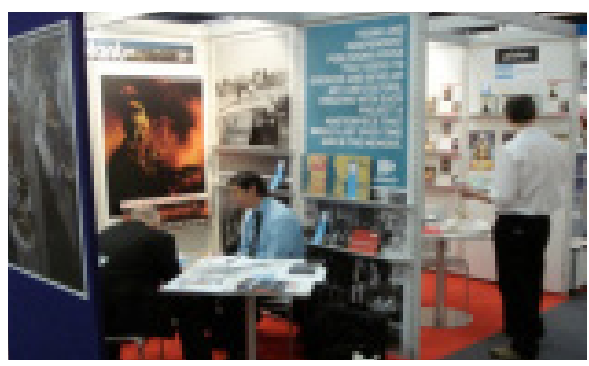

IMAGEN 22.

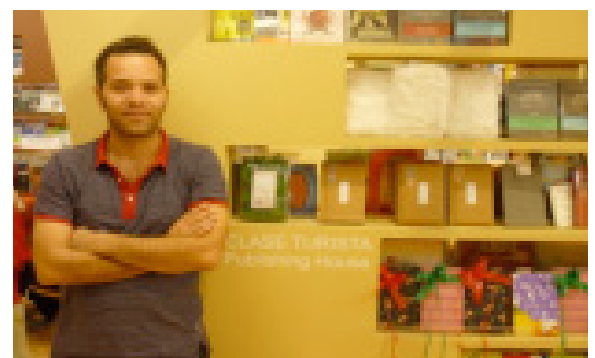

IMAGEN 19.

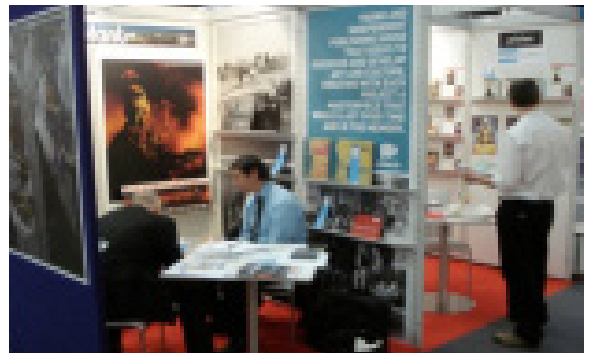

IMAGEN 21.

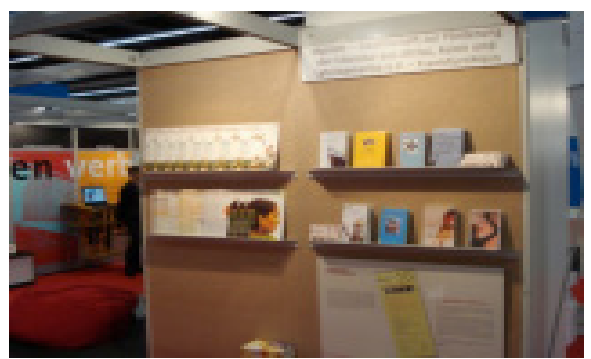

IMAGEN 23.

En 2010, muchos editores argentinos de pequeños emprendimientos se lanzaron a la aventura del viaje iniciático por dos motivos: uno por las expectativas generadas por la invitación del país y otro porque ir a la feria de Frankfurt es un deseo latente para cualquiera que haga libros, tal como una peregrinación a un lugar santo para un fiel creyente. Así vimos, entre muchos otros, a Lucas Castromán, con su editorial Clase Turista, la cual expresa intensa búsqueda experimental entre texto y objetualidad (imágenes 18 y 19). Estaban presentes editoriales como La Marca, Eterna Cadencia, Cuenco de Plata, un conjunto muy significativo entre las varias decenas de editores argentinos aparecidos tras la crisis de 2001 y la concentración del mercado. Son los actuales editores de riesgo que pueden contarse en gran número en el actual escenario de la cultura argentina. Se trata de proyectos que uno podría calificar como sofisticados; que no sólo trabajan sobre géneros, autores, estilos que no absorbe el 
gran mercado (incluida una buena proporción de traducciones), sino que también actúan en circuitos paralelos a los grandes canales de "compra y venta de derechos". La mayoría fueron incluidos en el stand colectivo de la CAL, parcialmente financiado en aquella ocasión con fondos públicos. Estuvieron presentes en un marco de cierta formalidad y mostraron facetas de un comportamiento habitual, tal como demuestra su posición en las mesas de trabajo, recibiendo visitantes, organizando una agenda de trabajo y cargando informaciones en sus notebooks (imagen 18). Cada uno estuvo con sus estrategias y estilos, aunque condicionados por el espacio de la feria y sus reglas. Quien en 2010 puso en cuestionamiento tales reglas de modo más extremo, fue Matías Reck, de Milena Caserola.

Matías compró su pasaje a Frankfurt en 24 cuotas. A fines de septiembre de 2010 partió hacia Alemania. Primero se alojó en la casa de un amigo en Berlín. Luego lo convenció que lo acompañara a la feria de Frankfurt, siempre cargando una mochila llena de libros de su editorial. Según nos contó, el primer día vio un par de stands vacíos, en el sector de editores de América Latina. Pasó, miró, pensó, volvió a pasar, hasta que decidió okuparlo. Era un stand pequeño, sin atractivo alguno. Para decorar el lugar, pegó un poster de la Feria del Libro Independiente (A) ${ }^{16}$ (FLIA), que él y otros escritores y editores promueven en Buenos Aires desde 2006. Luego montó algunos de sus libros sobre las repisas. Un momento de tensión fue cuando Matías vio llegar a Dieter Schmidt, quien, como comisario del Pabellón, corroboraba en una lista la concordancia entre expositores y números de stand. Dieter se sorprendió al hallar al imprevisto expositor y comenzó a demandar las razones de la presencia. El episodio pudo haber terminado muy mal, si no fuera por una cadena de afinidades que permitieron contornear las reglas. Dieter, según Matías, contaba con un pasado Okupa y también mantiene, como puede, una editorial donde publicaría títulos "contra-culturales", afines a los de Milena Caserola. Dieter hizo "vista gorda" y allí quedaron Matías y su amigo. Con el correr de los días, ese lugar atrajo la atención de muchas personas. Era quizás el stand más exótico de la feria. En base a la curiosidad y la simpatía, Matías y su amigo allí fueron congregando pares y curiosos. En su stand se tomaba mate, se tocaba la guitarra, había clima festivo ${ }^{17}$.

$16 \mathrm{Al}$ aparecer entre paréntesis, la (A) final es usada alternadamente por sus enunciadores, como alternativa, autónoma, autogestionada, amiga, atcétera [sic, como reza en el catálogo $\mathrm{n}^{\circ} 9-2011$, p. 60- de )el asunto(]. )el asunto( es otro de los colectivos culturales en los que participa Reck.

17 Al tiempo que en la Argentina estalló la crisis de diciembre de 2001, Matías Reck colaboraba en el área de publicaciones del Centro de estudiantes de la facultad de Economía de la UBA y en Ediciones Cooperativas, un sello de libros académicos. Esta editorial en 2006 participó de la Feria Internacional de Buenos Aires y Matías atendió el stand. Él participaba de organizaciones sociales y en espacios culturales "independientes". En la feria tomó contacto con un grupo de editores y escritores que, guiados por la editorial Maldita Ginebra, demandaban que la entrada sea gratuita, que se abran espacios para editoriales independientes y subsidios para incentivar la publicación de autores fuera del mercado. Entre ellos surgió la idea de realizar una contra-feria. As nació la FLIA. Este acontecimiento colectivo dio lugar a la promoción de numerosas acciones de acción colectiva, en prácticas de edición, impresión, distribución, información, etc. A través de sus páginas web y catálogos es posible mapear la cantidad de editoriales que participan de la FLIA o que son identificadas por los organizadores de ese espacio como independientes. En el último catálogo de )el asunto(, declaran sumar más de 300 participantes, de los cuales la mitad pueden ser consideradas editoriales y no editoriales de autor, etc. 


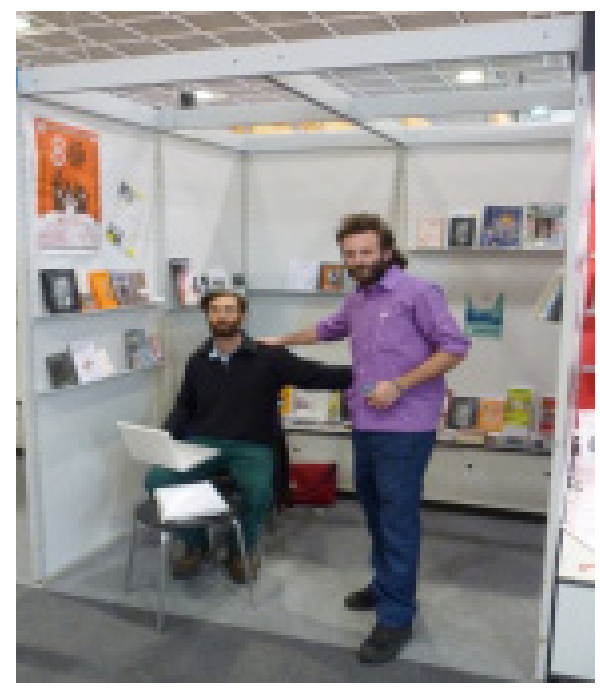

IMAGEN 24.

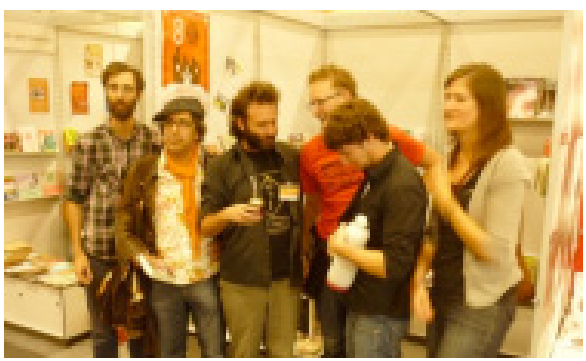

IMAGEN 26.

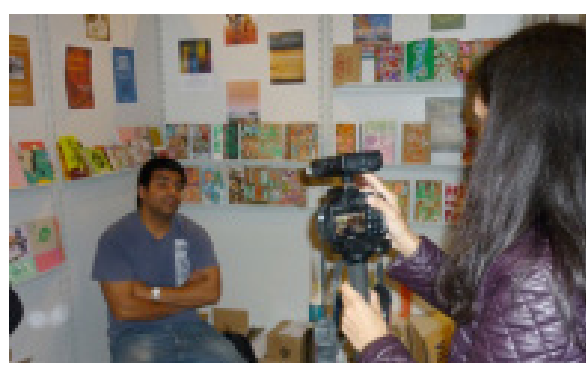

IMAGEN 28.

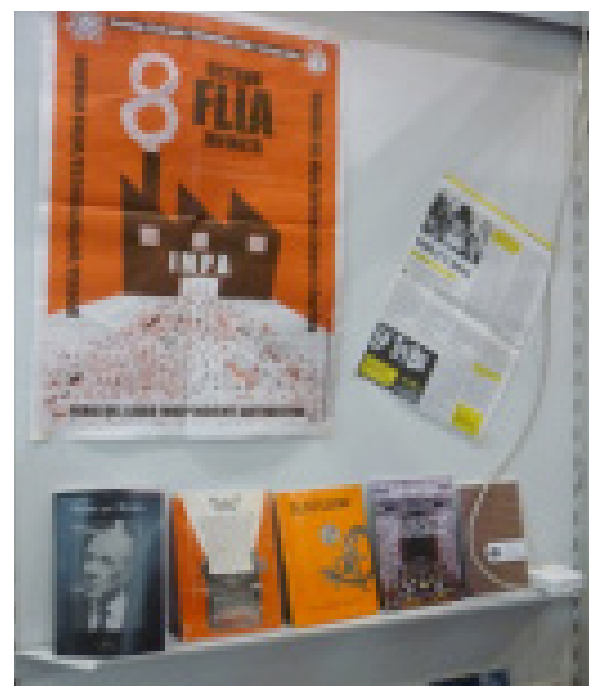

IMAGEN 25.

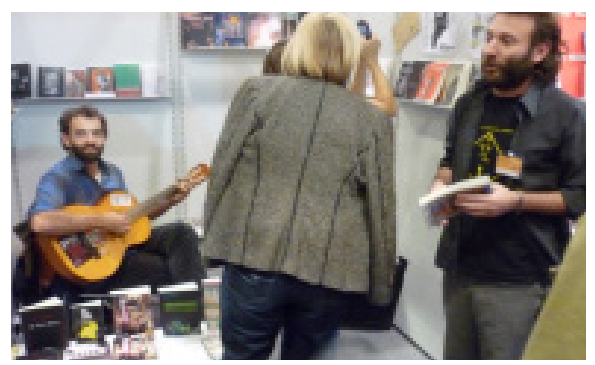

IMAGEN 27.

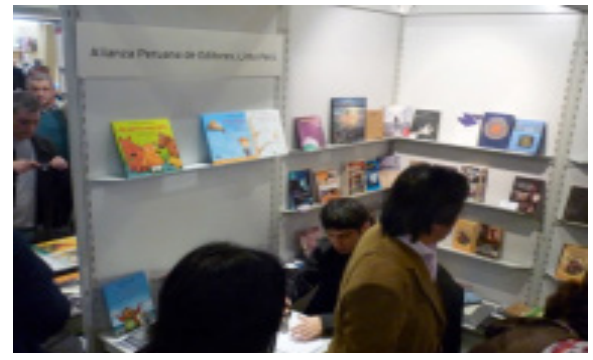

IMAGEN 29. 


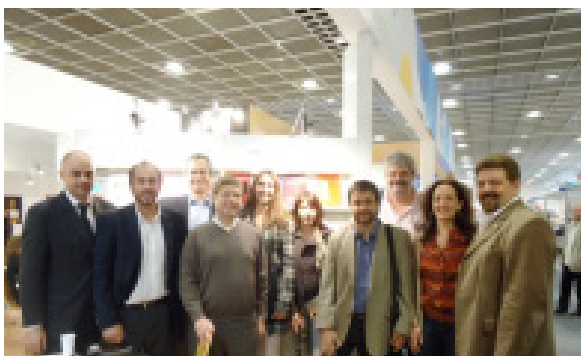

IMAGEN 30.

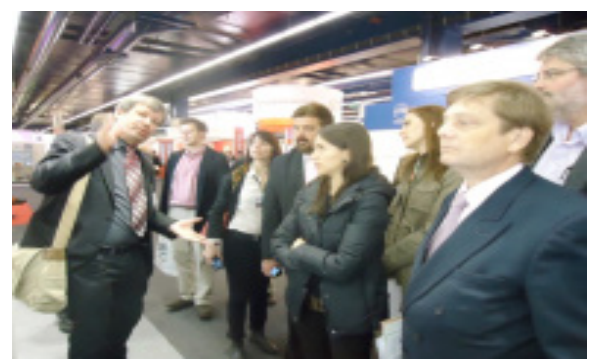

IMAGEN 31.

Tres stands contiguos a los ocupados por Matías, estuvieron vacíos durante los tres primeros días de la feria, jornadas reservadas para los profesionales. Al cuarto día, cuando se habilita el ingreso de público general, esos stands fueron ocupados. Uno por la Alianza de editores peruanos, organización reciente, homóloga a la Asociación de editores de Chile en tanto que escisión de "los independientes" (imagen 29). Otro, por editores latinoamericanos que exponían en el sector del Invitation Programme. Allá "abajo", estos editores ocupan un rincón marginal de la feria y si bien al subir la posición relativa no varía en gran medida, al menos esos editores ganaban otra visibilidad al aproximarse a una región cultural de pertenencia. El tercer stand fue ocupado por Washington Cucurto y su renombrada editorial Eloísa Cartonera. Este proyecto hoy en día es reconocido internacionalmente y ha inspirado editoriales homólogas llamadas “cartoneras” en Brasil, Bolivia y otros países de América Latina. Igualmente su modelo (fundado en el trabajo cooperativo en ideas como el reciclaje, la venta a bajo costo en lugares insólitos como clubes de barrio y verdulerías, la unicidad de cada libro armado artesanalmente con cartones pintados a mano) es copiado por universidades e instituciones civiles de variado tipo. Eloísa Cartonera es tan elocuente como metonimia de la crisis "ejemplar"18 argentina de 2001 y de la fuerza de la cultura para contornearla, que Cucurto fue a Frankfurt como expositor individual en el Kunst Museum de la ciudad. Allí, en el centro histórico, en un sitio de vanguardia estética, él disponía de un taller-instalación, donde montaba a la vista de los visitantes sus libros de literatura con tapas de cartón reciclado y pintadas a mano. Sin embargo se sentía aislado, como bicho raro. De allí su deseo de integrarse a la comunidad de la feria y aproximarse a los emprendedores culturales con mayor afinidad.

Finalmente no puede pasar por alto el registro de la participación de editoriales de universidades argentinas. Está fue casi inexistente hasta 2010, cuando el Ministerio de

18 En cuanto país donde se manifestaron de modo extremo las contradicciones del neoliberalismo (tan patentes en el escenario europeo del presente), gracias a la movilización política de una sociedad civil dispuesta a reconquistar sus derechos ciudadanos y la esfera pública. 
Educación inició un programa de apoyo para la promoción internacional de esta clase de agentes. En 2010 fueron cuatro y en 2011, cuando todo volvió a la normalidad y disminuyó sensiblemente la participación de editores independientes, el número de editoriales universitarias triplicó. Marifé Boix García y Dieter Schmidt tomaron nota de aquella singularidad de 2010 y para 2011 incentivaron la formación de un stand diferenciado para editores universitarios argentinos, separados por un pasillo del stand colectivo de la CAL. La edición universitaria si bien no es "independiente", también crece en significación y materialidad por efecto de lo que descarta la política de los grandes grupos. Es, por lo tanto, un emergente emparentado con el fenómeno de la edición independiente, al menos en países donde el Estado, con mayor o menor racionalidad, hace alianza con agentes estratégicos para las dimensiones políticas de la "diversidad cultural". Es preciso aclarar que en el caso de la Argentina el Estado siempre fue un actor insignificante para la promoción de la actividad editorial. Sólo en los últimos años, y en buena medida gracias a la chance-Frankfurt, el Estado argentino "intenta" estrategias de promoción internacional de la cultura nacional, como forma de afirmación de proyectos políticos.

\section{CONCLUSIÓN: ESTAR AQUÍ}

Realidad social, universo material, proceso histórico. A pesar de lo concreto que es el espacio de la edición independiente, quizás esta no pueda ser tratada más que como una representación, una creencia bien fundada. Ninguna propiedad sustancial parece identificar a la edición independiente: una clase de libros, un estilo de trabajo y organización, una comunidad de lectores predeterminada, un efecto cultural necesario. ¿Cuál es, en definitiva, su capital específico? ¿Hay consenso sobre su definición? ¿Qué sub-conjunto de editores reúne tal espacio en cada lugar donde se expresa el término edición independiente?

Es un acontecimiento. No hay dudas de que la edición independiente constituye un fenómeno visible como signo de los mercados editoriales contemporáneos. La edición "independiente" se torna palpable a partir de posicionamientos de tipo moral y discursos de estilo político que confluyen en posturas de resistencia frente a la concentración financiera de los conglomerados editoriales que dominan los mercados del libro desde hace dos décadas. La imposición de los intereses de la rentabilidad sobre los estéticos y simbólicos, o simplemente el aplastamiento de la cultura por la economía, dio lugar a las alertas y a los manifestos sobre las desapariciones del editor y de la bibliodiversidad, y la necesidad de colectivizar respuestas bajo las banderas de la primacía del valor ético, cívico del libro y el lugar de este objeto en la construcción o afirmación de la esfera pública. Como vemos, dos hechos concentran la atención cuando se piensa qué pasó en el mercado editorial internacional en su última 
fase: uno es la concentración de capitales y su manifestación en conglomerados; otro es la edición independiente. Un término está asociado al otro. Son opuestos complementarios. Interdependientes. Los define su relación y, en última instancia, no se puede comprender uno sin el otro. Forman una relación ponderable en una estructura que la abarca.

No toda editorial autónoma se identifica como independiente. No toda editorial independiente privilegia el capital simbólico. Ninguna de estas categorías es estática, sino que su dinámica está dada por la temporalidad de las prácticas y las transformaciones de los espacios en los que se desplazan los agentes y sus ideas, según el estado de las relaciones de fuerza entre todos los editores y otras figuras del mundo del libro. En un extremo, lo que baja del grupo Pearson, con sede en el Reino Unido, afecta las acciones de un colectivo editor anarquista que trabaja desde una fábrica recuperada del gran Buenos Aires, y la utopía de estos se orienta a afectar las estructuras a lo Pearson.

Hasta aquí estas conclusiones serían abstractas o generales, con afirmaciones semejantes a las que predominan en buena parte de los trabajos académicos sobre la edición independiente; área de estudios que parece formar una doxa desde el mismo momento en que surge. La aproximación etnográfica de mi trabajo buscó ir más allá de ideas del sentido común nativo y científico que ya decantan sobre la edición independiente y su mundo. Es a nivel de individuos concretos y enlazados con otros, en lugares y momentos precisos, donde se revela la arbitrariedad de lo diverso y lo palpable de las actuales realidades de las prácticas editoriales. No es igual el panorama en Europa y en América Latina, en Chile y en Argentina, en Frankfurt y en Buenos Aires. Pero al mismo tiempo un caso, debidamente anclado en espacios de relaciones, en escenarios descriptos, en coyunturas específicas y cambiantes, puede condensar de manera más poderosa los elementos generales que cualifiquen el fenómeno y cuestionen los supuestos universales. Aún así no sería suficiente el análisis si no hubiera modo de clarificar reflexivamente la distancia entre el objeto y el observador.

$\mathrm{Vi} \mathrm{a}$ aquel joven durante el inicio de mi trabajo etnográfico en la Feria de Buenos Aires (abril de 2010).Lovolvía verenFrankfurt(octubre).Apenas registrésu presencia, por el mandato etnográfico de la totalidad, pero sin pensar en su singularidad. En Frankfurt fotografié su stand y hablé con algunos editores independientes o pequeños, pero no con Matías Reck. Algunos me hablaron indirectamente de él, como "el de la Feria del libro independiente autónoma”. Pero un día volví a ver a Matías ... . jen mi propia "feria"! Participaba como un par, en el Primer Coloquio Argentino de Estudios sobre el Libro y la Edición, que organizamos en la Universidad de La Plata, a fines de octubre de 2012. Reck allí presentó el trabajo "Un posible final para un certero inicio: acerca de los nuevos desafíos de las editoriales independientes”, junto a Marilina Winik, quien figuraba en el programa como única autora. Lo hicieron en una de 
las dos mesas que ese evento dedicó a la edición independiente ${ }^{19}$. Allí expusieron la experiencia de la FLIA. La enmarcaron como expresión de las alternativas contraculturales ante la crisis neoliberal. Ponderaron el estado de debate y reformulación de las posibilidades de creación editorial y literaria que promovió esa feria, ante las constricciones de una "dictadura del mercado". Relataron el nacimiento de la FLIA en el contexto de las fábricas recuperadas por los trabajadores y del estado de asambleas generales que desafiaban el vaciamiento del Estado y recuperaban así el protagonismo cívico en la esfera pública. El "posible final" del título del trabajo de Winik y Reck aludía al adormecimiento o aburguesamiento de aquella rebeldía en muchos de los que inicialmente se sumaron a aquel movimiento "alternativo" de expresión cultural, el cual suponía un estado de reflexión permanente sobre las prácticas culturales y la política, lo que incluía debates sobre la función del editor, el lector, el librero, etc. Recky Winik se posicionaban como representantes de un último bastión crítico donde creen inevitable juzgar con escepticismo los rumbos que tomó la edición independiente hacia la rutinización del espíritu de resistencia inicial. Esta distancia "crítica" quedó objetivada en sus maneras de estar en Frankfurt y las de otros independientes que en aquéllos años post-crisis eran compañeros de batalla y ahora jugaban a la gran edición en el stand oficial del país. En sus textos, páginas web, en los paratextos de sus libros, es posible observar cómo Reck y algunos de sus pares de la FLIA a veces utilizan la palabra independiente entre comillas. No obstante, tal como la palabra bibliodiversidad, en algunos de esos soportes la independencia aparece como jalón identificatorio, pero en estado irreflexivo, sin comillas, denotando la naturalización y ambigüedad de aquella palabra y sus denotaciones en la edición contemporánea. En sintonía con cierta postura anarquista, Reck asocia la independencia a la idea de autonomía, por supuesto que también en relación al Estado que cobijaba todo lo que sucedía en la presentación Argentina, en Frankfurt 2010. En sentido contrario, hemos escuchado a otros editores independientes de perfil profesionalizado e internacionalizado, hablar despectivamente de proyectos como Milena Caserola y la FLIA, como posturas adolescentes que no pueden enfrentar la adultez que exigirín los avatares del mercado del libro. Reck y otros militantes de la FLIA se presentan explícitamente como actores anti-mercado, actitud que los orienta a explorar canales alternativos. El ejemplo admirado siempre es Elisa Cartonera, donde diariamente trabajan seis personas en forma de cooperativa, habitando inclusive un mismo terreno. Han ganado premios prestigiosos, pero todo es reciclado en proyectos donde no está en mira cambiar el formato artesanal de sus libros, ni desatender la venta callejera.

Estas representaciones conducen a problematizar el mundo de los editores independientes como espacio de diferencias donde la propia categoría de

19 Se trató del tema con mayor representación en el Coloquio, junto a la "Las editoriales de izquierda en la Argentina". 
clasificación nuclear es objeto de disputas, donde muchos participantes aparecen como agentes múltiples: como editores y también como intelectuales de "la edición independiente”. Bastaría avanzar la observación hacia los modos de representación y acción colectiva promovidos por diferentes colectivos, como la FLIA y el núcleo de poder institucionalizado de la edición independiente, representado por la Alianza internacional de editores independientes (con sede en París y en Argentina representado por Edinar), para comprender las oposiciones, contradicciones y conflictos que mueven el universo de la edición independiente.

Es imprescindible comprender que las acciones de los editores independientes que disputan la definición legítima de esa categoría, son aquellos que lo hacen en escala trasnacional. Tras su paso por la feria, Reck “fundó” Milena Berlín yluego Milena París. Se trata de emprendimientos de escasa actividad u ocasionales, encarados por “amigos de Matías”. En el presente se estarían creando "Milenas” en Córdoba, Rosario y otras ciudades argentinas y latinoamericanas. Eloísa Cartonera, vimos, ya no puede ser pensada sin los efectos de replicación nacional e internacional que generó. El caso LOM - Trilce - Era es ejemplar de esta clase de posicionamientos supranacionales como condición de diferenciación local de la edición independiente en Chile, Uruguay y México (Symmes, 2012). El sustento político-simbólico que aporta la Alliance a sus miembros, lleva a un límite la dimensión trasnacional en la que se define la edición independiente. Sin premeditación, como una condición estructural, lo trasnacional deviene una dimensión ineludible para los emprendimientos independientes pretensiosos y duraderos. Impuesta por la concentración financiera de los grandes grupos y por las tecnologías de la comunicación digital, lo trasnacional ya no es un criterio exclusivo para cualificar al perfil de los grandes grupos editoriales.

Pero volvamos a mi encuentro final con Matías Reck. "Ahora somos todos nativos", decía Clifford Geertz. Cuando el "campo" entra en casa, uno siente que está todo dado para explicar las cosas de raíz. Ello puede ser ilusorio si no se liga a una actitud reflexiva sistemática. Matías, ¿qué hacía aquí? Para el campo de estudios en ciernes sobre "la edición independiente", es imprescindible considerar que puede tratarse de un tema de alteridad mínima. Afectados por la estructura global de las condiciones de comunicación de las verdades que producen, las fracciones dominadas de las ciencias sociales y humanas no tienen como no hacer alianza con aquellos mediadores de la palabra impresa en posición de homología estructural. Pero una cosa es el hecho social y otra sus apropiaciones como objeto sociológico. El desfasaje y las diferencias entre ambas unidades permiten cerrar con reflexiones sobre cómo irrumpe este tema en nuestro arbitrario y cambiante universo de intereses académicos.

Para ello podemos remitir a la indispensable datación de la emergencia de la "edición independiente". Esta categoría, como afirmamos, es genéticamente correlativa a la aparición de los "grupos editoriales" de perfil concentrado y trasnacional. Si bien existen grupos de edición internacionalizados desde el siglo 
XIX (Garnier, Hachette, Jackson Inc., etc.), la fase actual remite a un fenómeno de la década de 1980, ya explorado por algunos autores (Mollier, 2000; Sapiro, 2009). Si bien el uso de la categoría "editores independientes" pudo ser usada con antecedencia, esta se instala definitivamente en el escenario como efecto de la visibilidad política o poder simbólico que le dio la Alliance International des Éditeurs indépendants, creada en $2002^{20}$. Al tiempo que emerge el reconocimiento de esta representación, surgen las disputas por su definición. En buena medida la sociología de la edición gana cuerpo en paralelo a estos procesos y muestra inevitablemente cierto desfasaje en el estudio y caracterización del fenómeno de la independencia. El coloquio de París o la sobre-representación de trabajos dedicados a la edición independientes en el Primer coloquio argentino de estudios sobre el libro y la edición (realizados ambos en octubre de 2012), manifiestan quizás una evidencia del aludido desfasaje. La convergencia en curso entre hecho social y objeto sociológico, debería alentar a no perder de vista la reflexividad y la crítica, más aún cuando muchos delos investigadores que participan de este campo de estudio son también agentes activos en espacios de la edición independiente. Luego, la indagación de la propia relación (o, mejor, "alianza”) entre independientes y académicos debe ser parte decisiva de la caracterización de los objetos dedicados a este tema.

En La Plata, con Matías nos escuchamos mutuamente. No fue difícil entrar en sintonía. Tras escuchar mi ponencia sobre Peter Weidhaas y América Latina, Matías me invitó a publicar con ellos. Luego, por mail, comenzamos a intercambias textos. La posibilidad de un entendimiento con Reck está en el reconocimiento de nuestras diferencias. En definitiva, yo no soy editor como él no es académico. En un límite, quizás a Matías le genere dudas mi comportamiento aggiornado en el mundo académico como a mi pensar el riesgo de editar un libro por una editorial imprevista o muy distinta a las deseadas en mi círculo de pares, como las célebres Fondo de Cultura Económica, Siglo XXI, Paidós, etc.

No estaba en mis planes estudiar la edición independiente. La invitación de Constanza Symmes y Sophie Noël, organizadoras del coloquio de París, y el manejo de materiales de campo que me invitaron a realizar, me encausaron a trabajar sobre lo que al final de este texto parece inevitable, central y revelador. Si aquí expuse alguna novedad, fue producto de la frescura de este momento de investigación inesperado. El desafío, como siempre, reside en no abandonar la actitud reflexiva. De lo contrario, uno corre el riesgo de sufrir el anquilosamiento de la mirada, tal como pudo haber sucedido a ciertos editores independientes ya estabilizados en el mainstream del sistema editorial, según la mirada de Matías Reck.

20 Como demuestran Bustamante y Symmes (2013), esta clase de acciones promovieron la promulgación, en 2005, de la Convención sobre la protección y la promoción de la diversidad de las expresiones culturales de la UNESCO. 


\section{Referencias bibliográficas}

Bustamante, M.y Symmes, C. (2013). Estructura y dinámicas de un capital simbólico trasnacional. Condiciones sociales del ingreso de la diversidad cultural en Chile. Revista del Museo de Antropología, 6.

De Diego, J. L. (2012). ¿Es posible hablar de un "campo editorial global”? Un análisis acerca de los agentes, mediaciones y prácticas en el espacio editorial trasnacionalizado". Actas del Primer coloquio argentino de estudios sobre el libro y la edición.

Dujovne, A. y Sorá, G. (2010). Un hecho de política cultural: Argentina en la República Mundial de la Edición. En Argentina país invitado de honor Feria del Libro de Frankfurt 2010 (pp. 217-223). Buenos Aires: Ministerio de Relaciones Exteriores, Comercio Internacional y Culto.

Mollier, J. (Dir.). (2000). Où va le livre? Paris : La Dispute.

Ruibal, S. (s.f.). La movida. Una etnografía de la poesía de vanguardia en Córdoba (2005 - 2012). Tesis para optar al grado de Master en Antropología, Universidad Nacional de Córdoba, Córdoba (en curso).

Sapiro, G. (Dir.). (2009). Les Contradictions de la globalisation éditoriale. Paris : Nouveau Monde.

Sorá, G. (2011). Editar la nación. Bicentenario argentino en Frankfurt. En Batticuore, G. y Gayol, S. (Orgs.), Tres momentos de la cultura argentina: 1810, 1910, 2010 (pp. 153-181). Buenos Aires: Prometeo - Editorial de la Universidad Nacional de General Sarmiento.

Symmes, C. (2009). La dimension culturelle de la transition politique chilienne: Le cas de la maison d'éditions Lom. Tesis para optar al grado de Master 2 Sciences Sociales (Recherche en Sociologie), École des Hautes Études en Sciences Sociales, Paris.

Symmes, C. (2012). Edición independiente, espacio público y transición política en Chile. Trabajo presentado en el Congreso de la International Sociological Association, Agosto, Buenos Aires.

Vulponi, A. (2012). Antropología e historia de la literatura infantil y juvenil en Córdoba. Tesis para optar al grado de Master en Antropología, Universidad Nacional de Córdoba, Córdoba.

Weidhaas, P. (1999), Historia de un alemán atípico. Los años de formación de un manager de la cultura. Buenos Aires: Ediciones de la Flor.

Weidhaas, P. (2007). A history of the Frankfurt book fair. Toronto: Dundurn Press.

Weidhaas, P. (2010) See you in Frankfurt. Life at the Helm of the largest book fair in the world. Nueva York: Locus.

Winik, M. (2010). Aportes críticos para la construcción del acontecimiento cultural: Feria del Libro Independiente y (A). Instituto de Investigaciones Gino 
Germani de la Facultad de Ciencias Sociales de la UBA. Seminario: Prácticas antagonistas en arte/política en América Latina desde los años sesenta, dictado por Ana Longoni y Fernando Davis.

Winik, M. (2011). Okupaciones textuales: deconstrucción de sentidos y acciones en la narración de un (no) acontecimiento. Mimeo. 